DOI: 10.47026/1810-1909-2021-2-87-94

УДК 398.44

ББК 82.3

\title{
А.Ф. ИЛИМБЕТОВА
}

\section{СИМВОЛИКА АЖДАХИ В ФОЛЬКЛОРЕ И ВЕРОВАНИЯХ БАШКИР}

\begin{abstract}
Ключевые слова: Аждаха, башкиры, змея, культ, мировоззрение, фрольклор, верования.

Статья посвящена анализу одного из ключевых змееликих персонажей - Аждахе в народном творчестве и религиозно-мистических представлениях башкир. Цель работы - провести анализ представлений, связанных с образом Аждахи, по данным фольклорных и полевых материалов и попытаться выявить его истоки. Научная новизна статьи заключается в том, что в работе впервые предпринимается попытка изучения причин почитания образа Аждахи у башкир. A это дает возможность воссоздать те или иные аспекты этнической истории башкирского народа, способствует выявлению исторических и генетических корней их духовной культуры. Методологическую основу исследования составил принцип аналитического и ретроспективного анализа литературных, фольклорных и лингвистических источников. В работе впервые систематизированы и проанализированы историкоэтнографические и фольклорно-лингвистические материалы по рассматриваемой теме. Введены в научный оборот фольклорные сведения, полевые материалы автора, впервые переведенные автором на русский язык. Практическая значимость исследования заключается в том, что представленные материалы способствуют раскрытию генетических корней обожествления змеи в фольклоре и мифологии башкир, могут быть использованы этнографами и фрольклористами в их сравнительно-исторических исследованиях. Исследовав проблему, автор пришел к выводу о том, что в башкирской религиозно-мифологической и фольклорной традиции образ Аждахи фрормировался на базе дальнейшей эволюции первобытных тотемических представлений о змее-тотеме, тотемическом предке и духе-покровителе и является следствием его сакрализации. В религиозно-мистических представлениях башкир этот образ стал отрицательным персонажем в результате поражения в этнокультурных и межрелигиозных столкновениях, а также вследствие неадекватного восприятия потомками древнейших тотемических инкарнационноинициационных обрядов и умозрений. Формирование представлений об образе Аждахи у башкир произошло не только под влиянием индоиранских фольклорномифологических традиций. В данном процессе кроме древних арийских охотников и собирателей (скотоводов и земледельцев) принимали участие предки афразийских народов, а также дахо-турано-тюркских племенных образований.
\end{abstract}

Введение. Проблема культа змеи, в частности образа Аждахи, всегда вызывала особый интерес в этнологии. До сих пор остаются дискуссионными вопросы его возникновения, становления и формирования. Поэтому исследования, обсуждающие те или иные стороны образа Аждахи, представляются актуальными и своевременными. В башкирском народном творчестве Аждаха изображается змееобразным демоническим существом, однако такая трактовка этого образа несколько пристрастна, так как она, по сути, змея же, отличается от других аналогичных почитаемых змей только долголетием, огромными размерами и обладает франтастической силой. Поэтому вполне правомерно распространить на нее те же взгляды, что и на почитаемую змею, которые формировались на базе древнейших тотемических мировоззрений, прежде всего представлений о сходстве человека и змеи, о происхождении их друг от друга, о змее как о тотемическом предке и покровителе. Данный постулат подкрепляется фольклорно-мифологическими материалами. Так, в мифах и сказках башкир Аждаха представлена как необыкновенная особь животного мира, обладающая даром перевоплощаться в человека, вести человеческий образ жизни, 
выступает в роли помощника, покровителя, оператора или патрона инициации, родоплеменного божества древних башкир. Целью исследования являются анализ образа Аждахи в фольклоре и верованиях башкир и попытка выявления его истоков. В целом башкирские исследователи в своих трудах так или иначе касались образа Аждахи. Однако большинство работ, посвященных этой теме, носили фррагментарный характер, где образу Аждахи уделялось лишь попутное внимание. С целью восполнения этого пробела мы рассматриваем образ Аждахи у башкир в предлагаемой статье.

Аждаха в фольклоре и верованиях башкир. В башкирской научной литературе, фольклоре и поверьях Аждаха изображается змееобразным демоническим существом, злым духом - людоедом, драконом. Однако, по нашему мнению, такая трактовка образа Аждахи несколько априорная.

Во-первых, Аждаха - это, по сути, змея. Она или (он) отличается от других змей только долголетием [11. С. 17]. Аждахой может стать столетняя змея, если она в течение своей продолжительной жизни ни разу не попадалась на глаза людей. В литературе встречается и противоположный тезис: столетняя змея перерождается в Аждаху только в том случае, если встретится с человеком. Змея-аждаха, достигнув 500-летнего возраста, трансформировалась в Юху - в змею-оборотня. В то же время, согласно другим устным и письменным материалам, змея приобретает очертания Аждахи, прожив на белом свете 500 лет, а в Юху - 1000 лет [16. С. 74; 18. С. 7].

Во-вторых, аждахи отличаются от других змей своими размерами. Если информанты говорят, что аждахи достигают в длину от двух-трех до несколько десятков метров, то в сказках ее длина измеряется километрами. А в эпосе «Урал-батыр» змей Кахкахи, охраняющий дворец падишаха, предстает как существо, «похожее на гору, высотой до небес» [2. С. 89, 299].

Согласно фольклорно-мифологическим данным и рассказам информантов, аждахи имеют, как правило, большую голову [3. С. 231; 11. С. 16]. Тем не менее в башкирской мифологии широко распространены и суждения о многоголовых аждахах. Так, в сказаниях «Ахмет-батыр и Худайбирде-батыр» и «Девушка-змея и Ванюшка» действуют двуглавые аждахи. Трехголовая Аждаха присутствует в фольклорном рассказе «Золотая сорожка»; шестиголовая - в легенде «Алпамыша-батыр». Семиголовые аждахи упоминаются в народных повествованиях «Алтындуга-батыр» и «Тимирхан». Данные о девятиголовой Аждахе представлены в новелле «Аюголак», о двенадцатиголовой - в устном рассказе «Минейбатыр и царь Шульган» и о тысячеголовой змее - в мифе «Джигит, победивший тысячеголовую Аждаху», и др. [3. С. 37, 64-65, 83-84, 97; 5. С. 170].

В-третьих, Аждаха по сравнению с обыкновенной змеей обладает фантастической физической силой и мощью, при движении которой поднимается страшный вихрь, пыльная буря заслоняет свет (сказания «Акъял-батыр», «Ахмет-батыр и Худайбирде-батыр» и др.). Когда она (он) плавает по морю, кипит океан (сказки «Девушка-змея и Ванюшка», «Золотая сорожка» и др.), поднимаются волны высотой с дом («Сын волка Сынтимер-пехлеван»). От его громового рева содрогается земля («Миней-батыр и царь Шульган», «Алпамышабатыр» и др.). Своим дыханием может притягивать батыров или девушек к себе в пасть («Летающий осел», «Справедливый царь» и др.) [3. С. 54, 66, 83, 141, 153-154; 4. С. 94, 131; 5. С. 170].

Если Аждаха разнится от змей только своим долголетием и сверхъестественными физическими качествами, то вполне правомерно распространить 
на нее (него) те же «змеиные параметры», которые формировались на базе древнейших тотемических мировоззрений, прежде всего представлений о тождестве человека и змеи, о происхождении их друг от друга, о змее как о тотемическом предке и покровительнице (покровителе) определенных сообществ древних людей.

Данный постулат подкрепляется и фольклорно-мифологическими материалами. Например, в сказках «Умурзак-батыр» и «Юноша-пастух» и других Аждаха общается с героями на человеческом языке, в новелле «Килтяй мэргэн и его сестра» она принимает вид женщины, в устных произведениях «Жена-аждаха» и «Летающий осел» сожительствует с мужчинами. В эпосе «Уралбатыр» царь змей Кахкаха, сбросив облачение из шкуры Аждахи, мог перевоплощаться в мужчину. В преданиях «Бииш-батыр» и «Караса-батыр» Аждаха сватается или вступает в брак с земными девушками [2. С. 86, 297; 3. С. 47, 120-121; 4. С. 132, 243, 369; 243; 5. С. 289].

В устнопоэтическом народном творчестве башкир Аждаха нередко выступает в роли благодетельного помощника и заступника молодого человека. Например, в притче «Тимирказык» Аждаха доставляет джигита на себе туда, куда он пожелает. В сказке «Красная подушка» храбрец прилетает домой на семиголовом Аждахе, который уничтожает неприятельское войско, разрушает страну противников, убивает враждебного царя, а затем строит для молодца новый город, делает его царем возрожденной страны [5. С. 152, 163].

В легенде «Мальчик и девочка» содержится инфрормация об употреблении в пищу головы Аждахи в качестве лечебного средства [12. С. 21]. Это дает повод для размышления о том, что в более древние времена предки башкир, повидимому, причащались мясом змеи (Аждахи), их тотемического предка и необыкновенного покровителя, с целью приобщения к тотему, приобретения его искомых свойств (в частности, долголетия и «бессмертия»).

В сказке «Курукса-батыр» Аждаха величиной с гору проглатывает невесту батыра и ныряет в озеро. Курукса-батыр убивает людоеда, вспарывает ему живот и оттуда живой и невредимой выходит девушка. Вполне допустимо отнести к осколкам аутентичных мифов многочисленные устные рассказы башкир, в которых аждахи являются хозяевами водных источников, ежедневно (варианты: каждую неделю, ежегодно) поглощают по очереди девушек аула, достигших совершеннолетия («Молодец и Аждаха», «Сын волка Сынтимер-пехлеван», "Хасан и Хусаин») [3. С. 141, 219, 222, 231; 4. С. 136].

Рудименты веры древних башкир в Аждаху как в оператора инициации ясно проступают в народных повествованиях о похищении громадными летающими змеями девушек, достигших совершеннолетнего возраста. В этиологической легенде «Цветок Юндуз» девушку во время прогулки Аждаха уносит в подводный мир и женится на ней. Аждаха похищает земную девушку и в устном произведении «Золотая птица» [4. С. 283]. Как известно, мифологические мотивы похищения и унесения тем или иным хтоническим существом молодых людей являются эвфемизмами проглатывания оператором или патроном инициации (в том числе чудовищным змеем) подвергаемых инициации юношей и девушек [8. С. 526-528, 574].

Реминисценции представлений об Аждахе как духе-покровителе инициационных обрядов просматриваются в богатырских сказках башкир «Умурзакбатыр», «Джигит, победивший тысячеголового аждаху» [3. С. 47-48, 97] и в других (более чем в 30 устных рассказах), в которых герои одолевают в еди- 
ноборстве Аждаху и удостаиваются звания батыра. Общепризнано, что все подвиги, совершаемые сказочными богатырями, являются отражением в фрольклоре древних церемоний принятия подростков, молодежи в группу полноправных членов рода (племени), испытанием их физических и моральных качеств.

Изложенные выше материалы не дают никаких оснований отнести Аждаху к числу мифических зловещих мизантропических существ. В них они выглядят как необычайные особи животного мира, обладающие даром преображаться в человека, вести человеческий образ жизни, предстают в амплуа помощника, покровителя, оператора или патрона инициации, родоплеменного божества древних башкир. Когда в 922 г. секретарь посольства Багдадского халифа в Волжскую Булгарию Ахмед Ибн-Фадлан в своем дневнике писал о поклонении одной из групп башкир змеям как божествам [6. С. 94], то он, скорее всего, имел в виду именно такие воззрения древних башкир о змеях, включая и сакральную Аждаху.

Атавизмы культа Аждахи дают себя знать в устной словесности казанских татар (Аждаха), сибирских татар (Аштаха), тарских татар (Аждага), мишарей (Аздяка), чувашей (Астаха), марийцев (Аждаха), казахов (Айдагар), киргизов (Аждахар), каракалпаков (Аждарха), узбеков (Аждарга), туркменов (Аждаха), турков (Аждарха), азербайджанцев (Аждаха), карачаевцев (Аждагьан), ногайцев (Аздага), ведических индийцев (Aхи), иранцев (Ажи-Дахака), белуджей Афганистана (Аждияр), таджиков (Аждаха), армян (Аждахак), греков (Эхидна, Эхион), болгар (Аждер / Аждраа), сербов (Аждайя), черногорцев (Аждайя), боснийцев (Аждайя), адыгейцев, кабардинцев, черкесов, лезгин (Аздага), аваров (Аждаха), древних персов (Аždahā) и других народов Южного Урала, Поволжья, Прикамья, Кавказа, Южной и Юго-Восточной Европы, Малой, Средней, Центральной и Южной Азии [1. С. 24; 9. С. 24; 10. С. 87; 13. С. 325; 14. С. 153; 20. C. 203-204].

Судя по накопленным материалам, качественные характеристики этих фольклорно-мифологических персонажей полностью совпадают с атрибутивными свойствами их вышерассмотренных башкирских аналогов.

Исторические корни культа Аждахи. В этнографической и религиоведческой литературе господствует мнение, что истоки культа Аждахи у народов Южного Урала, Поволжья, Прикамья, Кавказа, Южной и Юго-Восточной Европы, Малой, Передней, Средней, Центральной и Южной Азии связаны с иранской религиозно-мистической традицией и его название восходит к зоониму персидского мифологического персонажа Ажи-Дахака [1. С. 24; 9. С. 24-25; 14. С. $153 ; 18$. С. 7 и др.].

Однако, как свидетельствуют фольклорно-мифологические материалы, древние персы не почитали Ажи-Дахака. В «Авесте» - сборнике священных книг зороастризма (парсизма) - Ажи-Дахака изображается как трехглавый змей, творение Анхра-Манью, главы сил зла, тьмы и смерти. Ажи-Дахака один из сильнейших демонических дэвов, противостоящих благим божественным существам - ахурам. Имя Ажи-Дахака этимологизируют как двучленное слово, состоящее из древнеиндийского «аһi» - змей > авестийского «aži» - змей [7. С. 490, 527] + антропонима Дахака (имени одного из легендарных царей, захватившего власть над Ираном [9. С. 24]). В «Шахнаме» известен как Заххака, злой, кровожадный царь Ирана [17. С. 29, 32]. По мнению C.A. Маретиной, Ажи-Дахака в персидском языке буквально обозначает «жестокая змея» [10. С. 87]. 
C самого зарождения зороастризма в VII-VI до н.э. в Северо-Восточном Иране или в Средней Азии авестийцы (парсы?) вели непрерывные войны с соседними народами и государствами - аждахо - дэвопоклонниками за утверждение новой религии и расширение сферы своего влияния. Среди них наиболее могущественными противниками были туранцы Арало-Балхашского региона и дахо-массагеты Юго-Восточного Закаспия, которые в течение нескольких веков (c VI - по III вв. до н.э.) вели успешные боевые действия против экспансии иранцев. Наибольшей боевой ударной силой обладали дахи. Их латная конница и всадники-катафрактарии (в составе которых сражались и женщины) победоносно не только противостояли персам-ахеменидам, разгромив их армию и убив царя Кира II Великого (530 г. до н.э.), но и дали отпор Александру Македонскому (330 г. до н.э.). В исторической литературе существует постулат о принадлежности туранцев и дахов к тюркоязычным народам. Не менее грозной силой, отчаянно сопротивлявшейся иранским колонизаторам, были аждахопоклонники-мазендеранцы Южного Прикаспия, которые наголову разбили армию Кай Кавуса, второго царя из легендарной династии Кейянидов, и взяли в плен самого царя. Зороастризм стал государственной религией Парфянского царства и Сасанидского Ирана лишь при правлениях династий Аршакидов (250 г. до н.э. - 224 г. н.э.) и Сасанидов (224-651 гг. н.э.).

Как видим, зороастрийский Иран с северо-запада, севера, северовостока был подковообразно охвачен народами, почитавшими Ажи-Дахаку как первопредка, могущественного их покровителя. Здесь возникает вполне правомерный вопрос, почему их змееобразный сакральный первопредок носит чуждое, оскорбительное для них имя «Ажи-Дахака» - «жестокая змея»?

Ответы на этот вопрос обнаруживаются в генеалогических мифах тех же народов - аждахо-дэвопоклонников. Так, цари Мидии (Малая Азия), правившие Персией до 558 года до н.э., возводили свои родословные к Ажи-Дахаку. Потомками Ажи-Дахака провозглашали себя правители Кабулистана начала I тыс. н.э. В некоторых источниках царь Заххак объявляется арабом по происхождению [9. С. 25]. Аждахо/айдагар признается змеиным обличьем легендарного предка тюркоязычных народов (в том числе башкир и казахов) Баба Туклы Чашлы Азиза/Баба Тукти Шашти Азиза/Баба Тукляса. То есть в этих легендах Ажи-Дахака (и другие варианты) выступает не в амплуа «жестокого змея» или «кровожадного правителя», а в качестве тотемического первопредка вышеназванных народов и, не вызывает сомнения, что зооним АжиДахака интерпретировался у них совсем по-иному.

В качестве рабочей гипотезы вполне логично этимологизировать имя АжиДахака как трехчленное слово, состоящее из «ажи» + «дах» + «ака», где «ажи»/«ази»/«ahi» - означает «змей» + «дах» - название народа + «ака»/ «аке»/«аге» и т.п. - в древнетюркском, уйгурском, хакасском, узбекском, башкирском, татарском, туркменском, общемонгольском, бурятском, эвенкийском, солорском, эвенском, ульчском, орокском, маньчжурском, юкагирском, китайском языках дают понятие «старший брат»; в киргизском, якутском, бурятском (диал.), эвенкийском (диал.) - «отец»; в турецком, азербайджанском, туркменском, якутском, бурятском (диал.), иранском означают «господин»; в маньчжурском - «государь» $[15 ; 19$. С. 40-45, 70]. Исходя из этих соображений, можно предположить, что у дахов Ажи-Дахака буквально звучало: «Змей-отец (предок, господин, покровитель) дахов». С установлением господства зороастризма над дахами их боги, в том числе Ажи-Дахака, в условиях насильственного на- 
саждения культа Ахура-мазды (главного доброго божества авестийцев), жестоких гонений и истреблений приверженцев древней веры в эпоху «антидэвовских законов» царя государства Ахеменидов Ксеркса I (V в. до н.э.) были объявлены зороастрийцами «жестокими змеями», «драконами».

Все это дает основание для размышления о том, что формирование иррациональных умозрений об Аждахе у народов Южного Урала, Поволжья, Прикамья, Кавказа, Южной и Юго-Восточной Европы, Передней, Средней, Центральной и Южной Азии произошло не только под влиянием индоиранских фрольклорно-мифологических традиций. В данном процессе кроме древних арийских охотников и собирателей (скотоводов и земледельцев) принимали участие как минимум предки афразийских народов, с одной стороны, и дахо-турано-тюркских племенных образований - с другой, которые в глубокой древности (в эпоху верхнего палеолита) развивались на Ближнем Востоке в рамках единой ностратической этнокультурной и этнолингвистической общности.

Выводы. Таким образом, в башкирской религиозно-мифологической и фольклорной традиции образ Аждахи формировался на базе дальнейшей эволюции первобытных тотемических представлений о змее-тотеме, тотемическом предке и духе-покровителе и является следствием его сакрализации. Аждаха стала отрицательным персонажем в результате поражения в этнокультурных и межрелигиозных столкновениях, а также неадекватного восприятия потомками древнейших тотемических инкарнационно-инициационных обрядов и умозрений.

\section{Литература}

1. Басилов В.Н. Аждарха // Мифологический словарь / гл. ред. Е.М. Мелетинский. М.: Сов. энцикл., 1991. С. 24.

2. Башкирский народный эпос. М.: Наука, 1977. 518 с.

3. Башкирское народное творчество (далее - БНТ). Кн. З. Сказки. Уфра: Башк. кн. изд-во, 1978. $351 \mathrm{c}$.

4. БНТ. Т. 3. Богатырские сказки. Уфа: Башк. кн. изд-во, 1988. 448 с.

5. БНТ. Т. 4. Волшебные сказки. Сказки о животных. Уфра: Башк. кн. изд-во, 1989. 512 с.

6. Валиди Ахметзаки Туган. Дневниковые записи Ибн-Фадлана // Ватандаш. 1997. № 7. C. $94-115$.

7. Гамкрелидзе Т.В., Иванов Вяч.Вс. Индоевропейский язык и индоевропейцы. Реконструкция и историко-типологический анализ праязыка и протокультуры: в 2 ч. Ч. 2. Семантический словарь общеиндоевропейского языка и реконструкция индоевропейской протокультуры. Тбилиси: Изд-во Тбил. ун-та, 1984. 1328 с.

8. Илимбетова А.Ф., Илимбетов Ф.Ф. Культ животных в мифоритуальной традиции башкир. Уфа: АН РБ, Гилем, 2012. 710 с.

9. Лелеков Л.А. Ажи-Дахака // Мифооогический словарь. М.: Сов. энцикл., 1991. С. 24.

10. Маретина С.А. Змея в индуистской мифологии (На материалах МАЭ). СПб.: МАЭ РАН, 2005. 140 c.

11. Полевые материалы авторы. 2001 г.

12. Рухи мирас:: Свердловск башкорттарының фольклоры. Өфө: Эшлекле дин., 2008. 260 с.

13. Салмин А.К. Праздники, обряды и верования чувашского народа. Чебоксары: Чуваш. кн. изд-во, 2016. 688 с.

14. Селезнев А.Г., Селезнева И.А. Культовые персонажи в традициях народного ислама Сибири: к изучению религиозного синкретизма в малых локальных культурных комплексах // Культурное наследие народов Сибири и Севера. Материалы Пятых Сибирских чтений. СПб.: МАЭ РАН, 2004. Ч. 1. С. 147-155.

15. Сердюк Ю.О. Менталитет персов. [Электронный ресурc]. URL: http:geo.1september.ru/article.php?ld=200302402 (дата обращения: 12.08.2020). $146 \mathrm{c}$.

16. Сулейманова М.Н. Доисламские верования и обряды башкир. Уфа: РИО БашГУ, 2005.

17. Фирдоуси. Шах-наме. М.: Худож. лит., 1972. 798 с. 
18. Хисамитдинова Ф.Г. Мифологический словарь башкирского языка. М.: Наука, 2010. 456 с.

19. Цинциус В.И. К этимологии алтайских терминов родства // Очерки сравнительной лексикологии алтайских языков: сб. ст. Л.: Наука, 1972. С. 15-70.

20. Omidsalar M. Aždahā in Iranian Folktales // Encyclopedia Iranica. Vol. 3, fasc. 2. L.a. N.Y., Routledge \& Kegan Paul, 1987, pp. 203-204.

ИЛИМБЕТОВА АЗАЛИЯ ФАТТАХОВНА - кандидат исторических наук, старшиЙ научный сотрудник отдела этнологии, Институт истории, языка и литературы Уфимского федерального исследовательского центра Российской академии наук, Россия, Уфа (ilimbetovazalia@mail.ru; ORCID: https://orcid.org/0000-0001-7945-9559).

\section{Azaliya F. ILIMBETOVA \\ THE SYMBOLISM OF AZHDAKHA IN THE FOLKLORE AND BELIEFS OF THE BASHKIRS}

Key words: Azhdakha, the Bashkirs, snake, cult, worldview, folklore, beliefs.

The article is devoted to the analysis of one of the key serpentine characters - Azhdakha in the folk art and religious and mystical representations of the Bashkirs. The purpose of the work is to analyze the ideas associated with the image of Azhdakha basing on folklore and field materials, and to try to identify its origins. The scientific novelty of the article lies in the fact that this work is the first attempt to study the reasons for the veneration of the image of Azhdakha among the Bashkirs. And this makes it possible to recreate certain aspects in the ethnic history of the Bashkir people, helps to identify the historical and genetic roots of their spiritual culture. The methodological basis of the research is the principle of analytical and retrospective analysis of literary, folklore and linguistic sources. This paper is the first to systematize and analyze historical-ethnographic and folklore-linguistic materials on the topic under consideration. Folklore information and field materials of the author, first translated into Russian by the author, are introduced into scientific circulation. The practical significance of the research lies in the fact that the presented materials contribute to the disclosure of the genetic roots of snake deification in the folklore and mythology of the Bashkirs, and can be used by ethnographers and folklorists in their comparative historical studies. Having studied the problem, the author came to the conclusion that in the Bashkir religiousmythological and folklore tradition, the image of Azhdakha was formed on the basis of further evolution of primitive totemic ideas about the snake-totem, totemic ancestor and patron spirit and is a consequence of its sacralization. In the religious and mystical visions of the Bashkirs, this image became a negative character as a result of defeat in ethno-cultural and interreligious clashes, as well as due to descendants' inadequate perception of the most ancient totemic incarnation-initiation rites and speculations. Formation of ideas about the image of Azhdakha among the Bashkirs occurred not only under the influence of IndoIranian folklore and mythological traditions. In this process, in addition to the ancient Aryan hunters and gatherers (cattlemen and grain-growers), the ancestors of the Afrasian peoples, as well as the Dakho-Turan-Turkic tribal formations, took part.

\section{References}

1. Meletinskii E.M., ed., Basilov V.N. Azhdarkha [Ajdarha]. Mifologicheskii slovar' [Mythological dictionary]. Moscow, Sovetskaya Entsiklopedia Publ., 1991, p. 24.

2. Bashkirskii narodnyi epos [Bashkir folk epic]. Moscow, Nauka Publ., 1977, 518 p.

3. Bashkirskoe narodnoe tvorchestvo. Skazki [Bashkir folk art. Fairy tales]. Ufa, Bashkir Publ. House, 1978, vol. 3, 351 p.

4. Bashkirskoe narodnoe tvorchestvo. Bogatyrskie skazki [Bashkir folk art. Heroic tales]. Ufa, Bashkir Publ. House, 1988, vol. 3, 448 p.

5. Bashkirskoe narodnoe tvorchestvo [Bashkir folk art]. Volshebnye skazki. Skazki o zhivotnykh [Fairy tales. Animal Tales]. Ufa, Bashkir Publ. House, 1989, vol. 4, 512 p.

6. Validi Akhmetzaki Tugan. Dnevnikovye zapisi Ibn-Fadlana [Ibn-Fadlan's diary entries]. Vatandash [Compatriot], 1997, no. 7, pp. 94-115.

7. Gamkrelidze T.V., Ivanov Vyach.Vs. Indoevropeiskii yazyk $i$ indoevropeitsy. Rekonstruktsiya $i$ istoriko-tipologicheskii analiz prayazyka i protokul'tury: v 2 ch. Ch. 2. Semanticheskii slovar' obshcheindoevropeiskogo yazyka i rekonstruktsiya indoevropeiskoi protokul'tury [Indo-European 
language and Indo-Europeans. Reconstruction and historical-typological analysis of the proto-language and protoculture: in 2 parts. Part. 2. Semantic dictionary of the common Indo-European language and reconstruction of the Indo-European protoculture]. Tbilisi, Tbilis. Univer. Publ., 1984, 1328 p.

8. Ilimbetova A.F., Ilimbetov F.F. Kul't zhivotnykh $v$ miforitual'noi traditsii bashkir [The cult of animals in the mythological tradition of the Bashkirs]. Ufa, Gilem Publ., 2012, 710 p.

9. Lelekov L.A. Azhi-Dakhaka [Aji-dahaka]. Mifologicheskii slovar' [Mythological dictionary]. Moscow, Sovetskaya Entsiklopediya Publ., 1991, p. 24.

10. Maretina S.A. Zmeya v induistskoi mifologii (Na materialakh MAE) [Snake in hindu mythology (Based on MAE materials)]. St. Petersburg, 2005, $140 \mathrm{p}$.

11. Polevye materialy avtory. $2001 \mathrm{~g}$. [Author's field materials, 2001].

12. Rukhi miras: fol'klor sverdlovskikh Bashkir [Spiritual heritage: folklore of the Sverdlovsk Bashkirs]. Ufa, 2008, 260 p.

13. Salmin A.K. Prazdniki, obryady $i$ verovaniya chuvashskogo naroda [Holidays, rituals and beliefs of the Chuvash people]. Cheboksary: Chuvash Publishing House, 2016, 688 p.

14. Seleznev A.G., Selezneva I.A. Kul'tovye personazhi v traditsiyakh narodnogo islama Sibiri: $k$ izucheniyu religioznogo sinkretizma $v$ malykh lokal'nykh kul'turnykh kompleksakh [Cult characters in the traditions of Siberian folk Islam: towards the study of religious syncretism in small local cultural complexes]. Kul'turnoe nasledie narodov Sibiri i Severa. Materialy Pyatykh Sibirskikh chtenii [Cultural heritage of the peoples of Siberia and the North. Materials of the Fifth Siberian Readings]. St.Petersburg, 2004, part. 1, pp. 147-155.

15. Serdyuk Yu.O. Mentalitet persov [Persian mentality]. Available at: http:geo.1september.ru/article.php?ld=200302402 (Accessed 2020, Aug. 12).

16. Suleimanova M.N. Doislamskie verovaniya i obryady bashkir [Pre-Islamic beliefs and rituals of the Bashkirs]. Ufa, Bashkir State University Publ., 2005, 146 p.

17. Firdousi. Shakh-name [Shah-name]. Moscow, Khudozh. literatura Publ., 1972, 798 p.

18. Khisamitdinova F.G. Mifologicheskii slovar' bashkirskogo yazyka [Mythological dictionary of the Bashkir language]. Moscow, Nauka Publ., 2010, 456 p.

19. Tsintsius V.I. K etimologii altaiskikh terminov rodstva [On the etymology of the Altai terms of kinship]. Ocherki sravnitel'noi leksikologii altaiskikh yazykov [Essays on the comparative lexicology of the Altai languages]. Leningrad, Nauka Publ., 1972, pp. 15-70.

20. Omidsalar M. Aždahā in Iranian Folktales. Encyclopedia Iranica. Vol. 3, fasc. 2. L.a.N.Y.: Routledge\&Kegan Paul, 1987, pp. 203-204.

AZALIYA F. ILIMBETOVA - Candidate of Historical Sciences, Senior Research Associate, Ethnology Department, Institute of History, Language and Literature, Ufa Federal Research Center of the Russian Academy of Sciences, Russia, Ufa (ilimbetovazalia@mail.ru; ORCID: https://orcid.org/0000-0001-7945-9559).

Формат цитирования: Илимбетова А.Ф. Символика Аждахи в фольклоре и верованиях башкир // Вестник Чувашского университета. - 2021. - № 2. - С. 87-94. DOI: 10.47026/1810-1909-2021-2-87-94. 